\title{
Oil Sludge Recycling by Ash-Catalyzed Pyrolysis-Reforming Processes
}

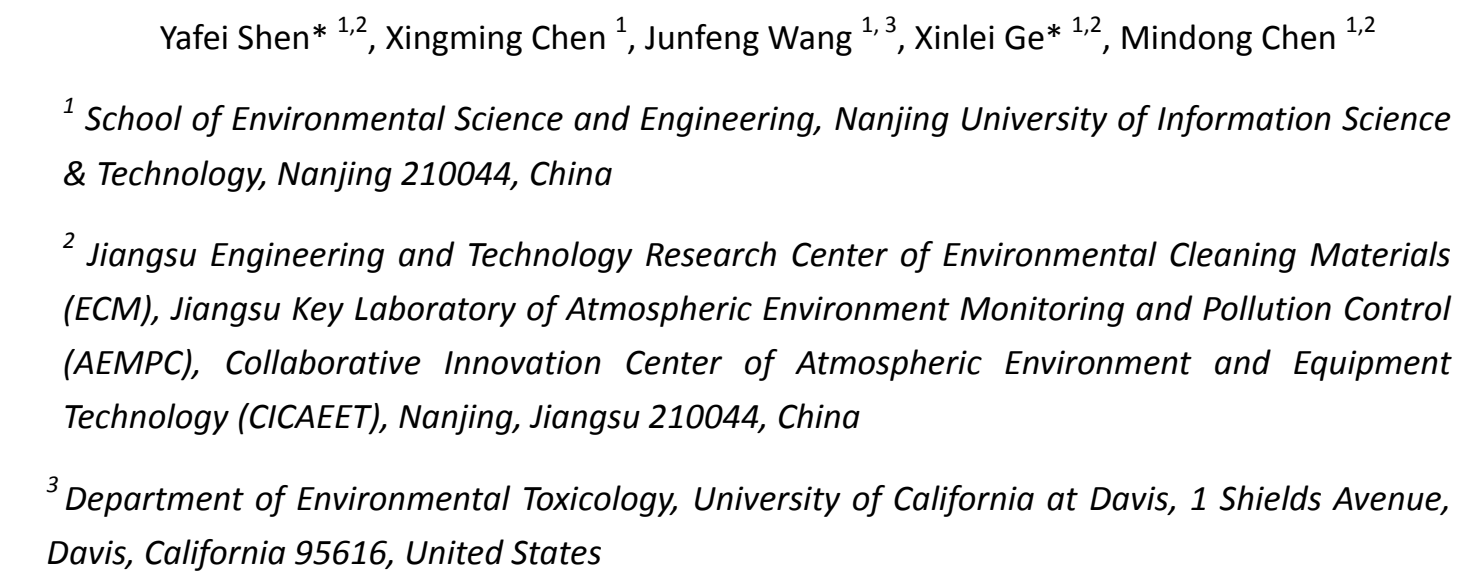

\section{ABSTRACT}

This paper proposed a sustainable method for fuel recovery from the oil sludge (OS) such as oil field sludge (OFS) and oil tank sludge (OTS) by the ash-catalyzed pyrolysis-reforming processes. The highest oil yield can reach $35.5 \%$ from the OTS co-pyrolysis with the OFS-ash. It can be attributed to the presence of iron and sulfur elements in the OFS-ash. Co-pyrolysis with the OFS-ash could also improve the contact between the OS and the catalyst resulting in the increase of oil yield. Compared with the OFS, oil recovery from the OTS was more considerable. However, the OFS-ash possessed a better catalytic performance on the pyrolysis vapor upgrading because of high metal (e.g., iron) contents. In addition, the highest HHV and cetane index (46.1 MJ/kg and 38.51) could be obtained when the oil from OFS co-pyrolysis with the OFS-ash was blended with the diesel with a volume ratio of 1:10. The range of carbon distillation of the mixed fuels (C7-C26) was identical with the diesel oil. And the saturate contents of the mixed fuels increased with the increase of the oil proportion. Therefore, mixing with the OS oil could slightly improve the quality of diesel.

Keywords: oil sludge (OS); pyrolysis; ash catalysts; reforming; diesel

\section{Corresponding Author}

*E-mail: shen1225@nuist.edu.cn (Y. Shen); caxinra@163.com (X. Ge) 


\section{INTRODUCTION}

Oil sludge (OS) is an inevitable by-product, which is generated in exploitation, transportation and refining processes of petroleum industry. It is a complex mixture of petroleum hydrocarbons and water with solid mineral admixture ${ }^{[1]}$. In general, OS consists of the oil field sludge (OFS) and the oil tank sludge (OTS) ${ }^{[2]}$. Both of them are abundant with toxic substances such as carcinogenic polycyclic aromatics, heavy metals, and radioactive materials, which possess high potential risks for human health and the environment ${ }^{[2]}$.

Storage and management of OS has become a crucial issue because of the hazardous nature of the OS which typically contians $10-12 \%$ solids, $30-50 \%$ water and $30-50 \%$ oil by mass fraction ${ }^{[3]}$. Currently, the most common route is immobilization and landfill, which requires large space and causes a serious threat to soil and groundwater environment. It is suggested that the recovery of oil is economically feasible if the OS contains at least $10 \% \mathrm{oil}^{[4]}$. The conversion of the OS to fuels and materials has been recognized as an attractive approach ${ }^{[4,5]}$.

Some chemical recycling methods such as solvent extraction or addition of the demulsifier have been used ${ }^{[5,6]}$, and they are indeed feasible in improving the rate of oil recovery. Nevertheless, these approaches require vast amount of extra organic solution or additives. Thermal disposal methods: incineration and pyrolysis can offer some considerable benefits over these methods in the aspects of energy recovery and waste reduction ${ }^{[7,8]}$. Due to the existence of the secondary pollution ${ }^{[9,10]}$ and the high viscosity of fuels ${ }^{[11]}$, the incineration of OS is limited. With its characteristics to crack high molecular weight organic compounds, and to separate the stable emulsion of OS into oil, water, and residue fraction efficiently, the pyrolysis has been widely used for the disposal of oily wastes ${ }^{[11-13]}$. It was proved that the pyrolysis oil was close to the diesel oil, but they contain certain amounts of heavy components (e.g., asphaltene), which mostly affect the qualities of oil products severely ${ }^{[14,15]}$.

The catalytic cracking/reforming has a great potential to shorten the reaction time, lower the reaction temperature and narrow the product distribution ${ }^{[16]}$. Commonly, the pyrolysis combined with reforming process was conducted in a two-stage setup, which mainly consists of a pyrolyzer 
and a reformer. As illustrated in Fig. 1, the catalysts could be employed in the pyrolyzer (i.e. in situ upgrading) and in the reformer (i.e. ex situ upgrading) ${ }^{[17,18]}$. Catalysts that were placed in contact with the feedstock inside of the pyrolysis reactor can improve the thermal conversion, and adjust the distribution of volatilized products ${ }^{[19]}$. However, the catalysts will be unfeasible to be frequently recycled from the solid residues. Likewise, the catalysts can be used in the downstream of the primary reactor for vapors upgrading ${ }^{[20]}$. Significantly, the deactivated catalysts could be much easier renewed and regenerated. So far, many types of catalysts have been used for the catalytic pyrolysis of oily wastes ${ }^{[21-25]}$. Lam et al. ${ }^{[22]}$ also found that the metallic pyrolysis char could be used for waste engine oil upgrading by catalytic microwave pyrolysis. In the commercial plants, the mineral-based catalysts such as $\mathrm{Al}_{2} \mathrm{O}_{3}$ and zeolites have attracted more attentions for the waste oils upgrading ${ }^{[26-28]}$. For example, ZSM-5 is considered to be a promising zeolite-based catalyst for pyrolysis vapor upgrading to produce considerable petrochemicals (e.g., aromatics and olefins) ${ }^{[29-32]}$. In our previous work, the zeolite catalysts (e.g., natural zeolite, ZSM-5) were used for the fuel oil production from two-stage pyrolysis-catalytic reforming of brominated high impact polystyrene ${ }^{[33,34]}$.

The aim of this work is oil recovery from OS by means of the pyrolysis-reforming process. The low-cost catalysts including zeolites (e.g., ZSM-5), activated $\mathrm{Al}_{2} \mathrm{O}_{3}$, and the by-product of ashes were comparatively studied for in situ and ex situ upgrading. The yields and properties of the oil products were characterized by comparing their distillation results with the diesel standard, FT-IR and NMR, respectively. Besides, the oil products by using the sludge ashes were blended with the diesel oil by the volume ratio of one-to-five and one-to-ten. The fuel characteristics of the oil mixtures were analyzed by GC-MS, and identified the viscosity, the density, the cetane index, the carbon number distribution and the heating value, respectively. 


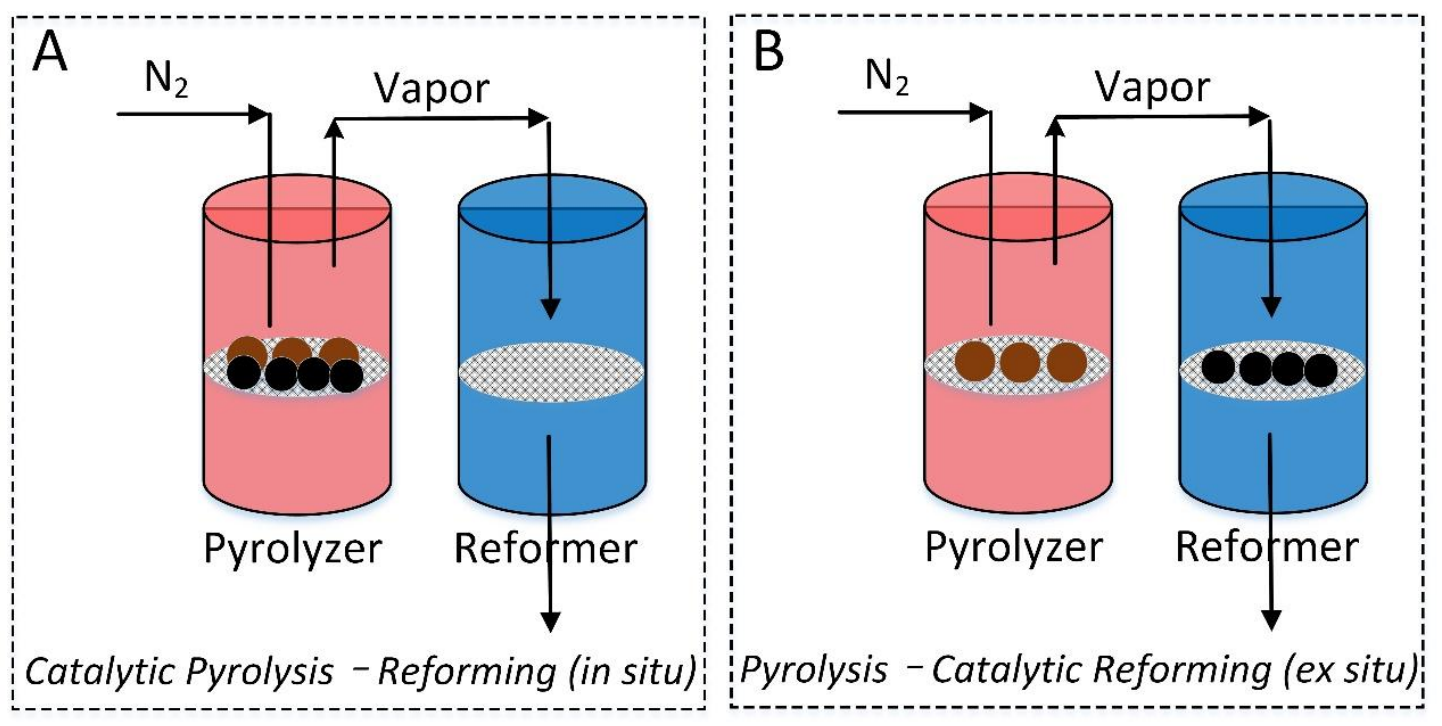

Figure 1. Schematic illustrations of (A) Catalytic pyrolysis-reforming (namely in situ upgrading) and (B) Pyrolysis-reforming (namely ex situ upgrading)

\section{MATERIALS AND METHODS}

\subsection{OS Samples and Catalysts}

The OFS and the OTS used in this study were sampled from Shengli oil field, Shandong, China. The OFS is finely gritty texture, which is wet by crude oil. As for the OTS, it generally is dark and viscous slurry, and no particulate materials can be found within it. Table 1 shows the results of the proximate analysis, the ultimate analysis, the higher heating value (HHV), the oil content and a part of metal elemental analysis. It can be found that the HHV and oil content of OTS are two-times higher than those of OFS. Compared with the OFS, the oil recovery from the OTS is more considerable. However, the contents of metal elements such as iron, copper, nickel in the OFS are much higher than those in the OTS. Consequently, the OFS-ash might possess a better catalytic performance on the pyrolysis vapor upgrading. 


\begin{tabular}{|c|c|c|}
\hline & Oil field sludge (OFS) & Oil tank sludge (OTS) \\
\hline \multicolumn{3}{|c|}{ Proximate analysis (wt.\%, as-received) } \\
\hline Moisture & 7.63 & 20.61 \\
\hline Volatile matters & 14.57 & 41.59 \\
\hline Fixed carbon & 0.84 & 4.62 \\
\hline Ash & 76.96 & 33.18 \\
\hline \multicolumn{3}{|c|}{ Ultimate analysis (wt.\%, dry-basis) } \\
\hline C & 16.89 & 58.97 \\
\hline $\mathrm{H}$ & 2.32 & 9.14 \\
\hline $\mathrm{N}$ & 0.16 & 1.21 \\
\hline$S$ & 0.53 & 1.91 \\
\hline $\mathrm{O}^{*}$ & 2.60 & 4.67 \\
\hline \multicolumn{3}{|c|}{ Metal elemental analysis (ppmw) } \\
\hline $\mathrm{Fe}$ & 14865.98 & 955.92 \\
\hline $\mathrm{Cu}$ & 22.55 & 2.36 \\
\hline $\mathrm{Ni}$ & 23.44 & 5.3 \\
\hline $\mathrm{V}$ & 20.28 & 18.54 \\
\hline $\mathrm{Na}$ & 164.35 & 620.31 \\
\hline $\mathrm{HHV}(\mathrm{MJ} / \mathrm{kg})$ & 10.45 & 21.51 \\
\hline Oil content (wt.\%) & 21.65 & 43.20 \\
\hline *Calculated by diffe & & \\
\hline
\end{tabular}

2 . 9

Five catalysts were selected for the catalytic upgrading. The OS ashes (OFS-ash and OTS-ash) were prepared by burning the pyrolytic residue of the OS in a muffle furnace at $600{ }^{\circ} \mathrm{C}$ for $3 \mathrm{~h}$. The properties of the catalyst samples were presented in Table 2. The commercial activated $\mathrm{Al}_{2} \mathrm{O}_{3}$ and ZSM-5 have higher BET surface areas compared with the OS ash and the natural zeolite (NZ).

From this table, it can also be found that the main components of the OFS-ash and the OTS-ash consist of $\mathrm{SiO}_{2}, \mathrm{Al}_{2} \mathrm{O}_{3}, \mathrm{CaO}, \mathrm{Fe}_{2} \mathrm{O}_{3}$, and $\mathrm{SO}_{3}$. Moreover, the main components of the $\mathrm{NZ}$ include $\mathrm{SiO}_{2}, \mathrm{Al}_{2} \mathrm{O}_{3}, \mathrm{CaO}, \mathrm{Fe}_{2} \mathrm{O}_{3}$, and $\mathrm{K}_{2} \mathrm{O}$. The chemical components of OS-ash are similar to the NZ. It has been proven that the NZ is effective and applicable to recovery the diesel range fuel from waste plastics ${ }^{[33]}$.

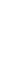
8 


\begin{tabular}{|c|c|c|c|c|c|}
\hline & OFS-ash & OTS-ash & $\begin{array}{l}\text { Natural zeolite } \\
\text { (NZ) }\end{array}$ & $\begin{array}{l}\text { Activated } \\
\mathrm{Al}_{2} \mathrm{O}_{3}\end{array}$ & $\begin{array}{l}\text { Commercial } \\
\text { ZSM-5 }\end{array}$ \\
\hline $\begin{array}{l}\text { Chemical } \\
\text { Constitutes }\end{array}$ & $\begin{array}{l}\text { a mixture of } \\
\text { metal oxides, } \\
\text { amorphous }\end{array}$ & $\begin{array}{l}\text { a mixture of } \\
\text { metal oxides, } \\
\text { amorphous }\end{array}$ & $\begin{array}{l}\text { crystalline } \\
\text { aluminosilicate } \\
\text { (with } \\
\text { impurities), } \\
\text { mordenite, } \\
\mathrm{SiO}_{2} / \mathrm{Al}_{2} \mathrm{O}_{3} \\
\text { (mole ratio): } \\
8.12\end{array}$ & $\begin{array}{l}\mathrm{Al}_{2} \mathrm{O}_{3} \\
\text { amorphous }\end{array}$ & $\begin{array}{l}\text { Crystalline } \\
\text { aluminosilicate, } \\
\text { mordenit, } \\
\mathrm{SiO}_{2} / \mathrm{Al}_{2} \mathrm{O}_{3} \\
\text { (mole ratio): } 80\end{array}$ \\
\hline $\begin{array}{l}\text { BET surface } \\
\text { area }\left(\mathrm{m}^{2} / \mathrm{g}\right)\end{array}$ & 4.74 & 135.34 & 50.54 & 319.93 & 425 \\
\hline $\begin{array}{l}\text { Pore volume } \\
\left(\mathrm{cm}^{3} / \mathrm{g}\right)\end{array}$ & 0.024 & 0.415 & 0.134 & 0.371 & 0.365 \\
\hline $\begin{array}{l}\text { Average pore } \\
\text { size }(n m)\end{array}$ & 20.57 & 12.28 & 10.61 & 4.64 & 4.51 \\
\hline $\begin{array}{l}\text { Pore } \\
\text { structure }\end{array}$ & mesopore & mesopore & mesopore & $\begin{array}{l}\text { mesopore } \\
\text { and } \\
\text { micropore }\end{array}$ & $\begin{array}{l}\text { mesopore and } \\
\text { micropore }\end{array}$ \\
\hline \multicolumn{6}{|c|}{ Chemical components (wt.\%) } \\
\hline $\mathrm{SiO}_{2}$ & 54.4 & 25.6 & 68.76 & - & \\
\hline $\mathrm{Al}_{2} \mathrm{O}_{3}$ & 11.5 & 40.3 & 14.4 & - & \\
\hline $\mathrm{CaO}$ & 9.69 & 6.79 & 10.47 & - & \\
\hline $\mathrm{Fe}_{2} \mathrm{O}_{3}$ & 8.29 & 7.7 & 4.24 & - & \\
\hline $\mathrm{K}_{2} \mathrm{O}$ & 3.6 & 1.09 & 1.08 & - & \\
\hline $\mathrm{MgO}$ & 1.76 & 1.37 & 0.45 & - & \\
\hline $\mathrm{Na}_{2} \mathrm{O}$ & 1.37 & 2.89 & 0.31 & - & \\
\hline $\mathrm{TiO}_{2}$ & 1.36 & 1.6 & - & - & \\
\hline $\mathrm{SrO}$ & 0.13 & 0.17 & - & - & \\
\hline $\mathrm{SO}_{3}$ & 7.11 & 11.1 & - & - & \\
\hline Ignition loss & 0.519 & 0.475 & 0.29 & - & \\
\hline
\end{tabular}

2

\section{2.2. Experimental Setup}

4 The pyrolysis-reforming experiments were conducted in a bench-scale setup as illustrated in Fig.2.

5 This system is mainly composed of the pyrolyzer and the reformer, which are covered with the

6 electrical heater, and the reaction temperatures in the pyrolyzer and the reformer are controlled

7 by a closed loop feedback system, including K-type thermocouples, a controller, and a heater. In

8 addition, a double-tube condenser is connected to the reformer for the liquid oil condensation. 


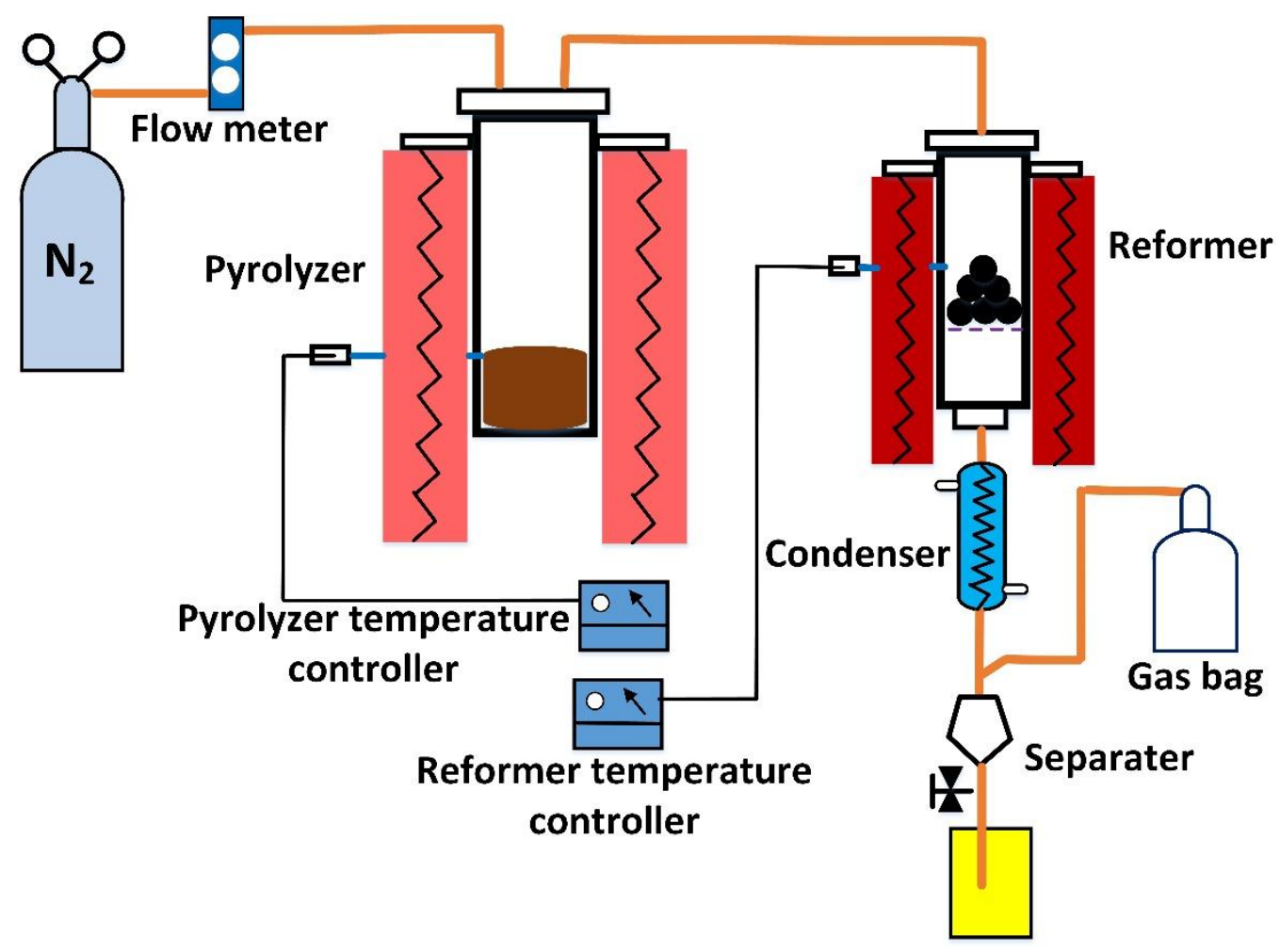

Figure 2. Schematic diagram of the experimental setup

3

4

5

6

\subsection{Experiment Procedure}

In the in-situ upgrading, the mixture of OS (60 g) and catalyst $(20 \mathrm{~g})$ was fed into the pyrolyzer. In the ex-situ upgrading, OS (60 g) and catalyst ( $20 \mathrm{~g})$ were separately placed in the pyrolyzer and the reformer, where $40 \mathrm{~g}$ of quartz sand were packed on the top surface of the catalyst to ensure that the catalyst was flatten and separated from the solid particles in the pyrolysis gas. $\mathrm{N}_{2}$ carrier gas with a flow rate of $50 \mathrm{ml} / \mathrm{min}$ initially passed through the pyrolyzer and reformer for $1 \mathrm{~h}$ to remove the extra air in the system. Afterward, the reformer was heated to $500{ }^{\circ} \mathrm{C}$ in order to dry and activate the catalysts. Additionally, the pyrolyzer was heated to $500{ }^{\circ} \mathrm{C}$ with a rate of 20 ${ }^{\circ} \mathrm{C} / \mathrm{min}$. When the temperature reached $390{ }^{\circ} \mathrm{C}$, the heating rate decreased remarkably due to the endothermic reaction of the OS. Furthermore, the temperature hovered at $395{ }^{\circ} \mathrm{C}$ for $2 \mathrm{~min}$. The quantity of pyrolysis gas increased as the temperature reached $450{ }^{\circ} \mathrm{C}$. Finally, the pyrolysis gas was reformed and introduced to the condenser for the gas-liquid separation. The products of liquid, gas and solid residues were collected separately.

\subsection{Analytical Methods}

The yields of liquid and solid products were obtained by weighing, and therefore the yield of gas 
product was estimated according to the difference. The oil products and the blended fuel oils were characterized by using the fourier transform infrared spectrometer (FT-IR, JEOL JIR-SPX200, Japan), the nuclear magnetic resonance (NMR, BrukerbiospinAvance III, Germany), and the gas chromatography coupled with the mass spectroscopy [GC-MS, Agilent 19091S-433 with HP-5MS Phenyl Methyl Siloxane $(30.0 \mathrm{~m} \times 250 \mu \mathrm{m} \times 0.25 \mu \mathrm{m})$ column $)$, USA], respectively.

\section{RESULTS AND DISCUSSION}

\subsection{The Yields of Pyrolysis Products}

The yields of pyrolytic products including gas, liquid (oil, water), and solid are shown in Fig. 3. Without the catalysts, the oil yields of OTS and OFS are $30.7 \%$ and $8.83 \%$, respectively. As for in situ upgrading, the oil product derived from the OTS with the OFS-ash is about $35.5 \%$ higher than those with other catalysts (31.53-22.95\%) (Fig. 3A). In Fig. 3B, the highest oil yield of 9.5\% is also obtained by co-pyrolysis of the OFS with the OFS-ash. Shie et al. ${ }^{[16]}$ thought that iron oxide and sulfur oxide could improve the thermochemical conversion of OS by inhibiting the agglomeration of metal oxides and increasing the surface area of catalysts. The presence of iron oxides and sulfur oxides in the OS ashes contributed on the high yield of oil products. Significantly, in terms of in situ upgrading, the OFS-ash could improve the contact between the OS and the catalyst, and result in the improvement of oil recovery corresponding to a higher oil yield by co-pyrolysis with the OFS-ash. Compared with other catalysts, the oil yield by using the OTS-ash remained a lower level, mostly due to their higher amounts of gas products, similar to that of the ZSM-5. Herein, it can be suggested that the OTS-ash has a higher catalytic activity or dispersive capacity than the OFS-ash. In addition, the gas yields from in situ upgrading are normally lower than those from ex situ upgrading. It proves that the catalysts functioned fully in ex situ upgrading, and enhanced the large molecules cracking into small ones (non-condensable gas molecules). In general, the yields of solid products derived from the catalytic pyrolysis of the OFS are generally above $80 \%$, owing to the high ash content of the OFS (Fig. 3B). 

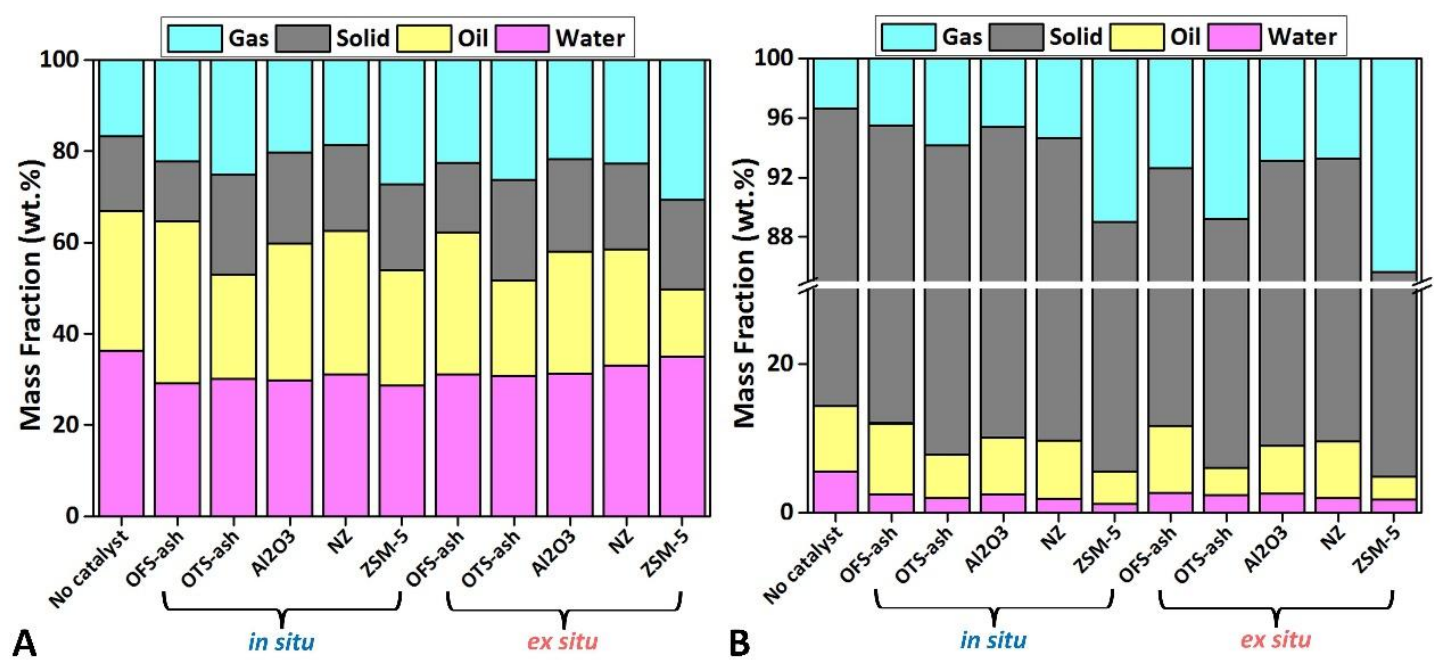

Figure 3. The yield and mass fraction of products from (A) OTS and (B) OFS pyrolysis

\subsection{Distillation Characteristics of the Oil Products}

The distillation characteristics of oil products with the range of boiling point (i.e. $30-400{ }^{\circ} \mathrm{C}$ ) were determined at the atmospheric pressure by a thermo-gravimetric instrument. It was revealed the boiling range of all the oil samples were between $90{ }^{\circ} \mathrm{C}$ and $370{ }^{\circ} \mathrm{C}$. The distillation characteristic curves are presented in Fig. 4 and Fig. 5. Besides, the ratio of remaining carbon at $450{ }^{\circ} \mathrm{C}$ shows the yield of coke in the oil product (as shown in Fig. 6). The ratio of remaining carbon can reflect the amount of carbon deposition when the oil products are used in an oil engine. Therefore, both the distillation characteristics and the ratio of remaining carbon are considered as the important evaluation parameters of oil quality. It can be found that the distillation characteristic curves of oil products, whether from the pyrolysis of the OFS or the OTS, are located between the curve for no catalyst oil product and the curve for diesel standard. It is suggested that the ranges of boiling points of all the oil products are in between the non-catalytic oil product and diesel standard. The results indicated that all the catalysts can improve the quality of oil products by decreasing their boiling point range. It can also be observed that the boiling range of the oil products with the OTS-ash (in situ: $124.5-284.5^{\circ} \mathrm{C}$; ex situ: $123.4-273{ }^{\circ} \mathrm{C}$ ) is the closest to the boiling range of diesel standard $\left(144-248.4^{\circ} \mathrm{C}\right)$. 

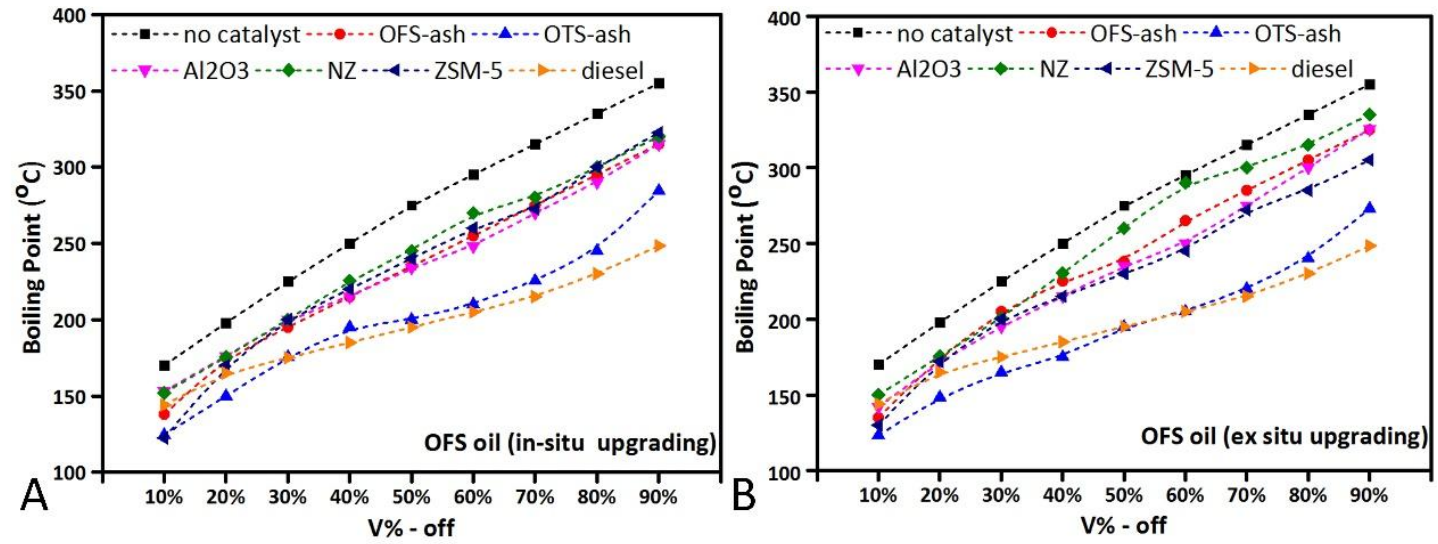

Figure 4. Boiling point range distribution of the oil product from the OFS pyrolysis $(A)$ in situ and (B) ex situ upgrading
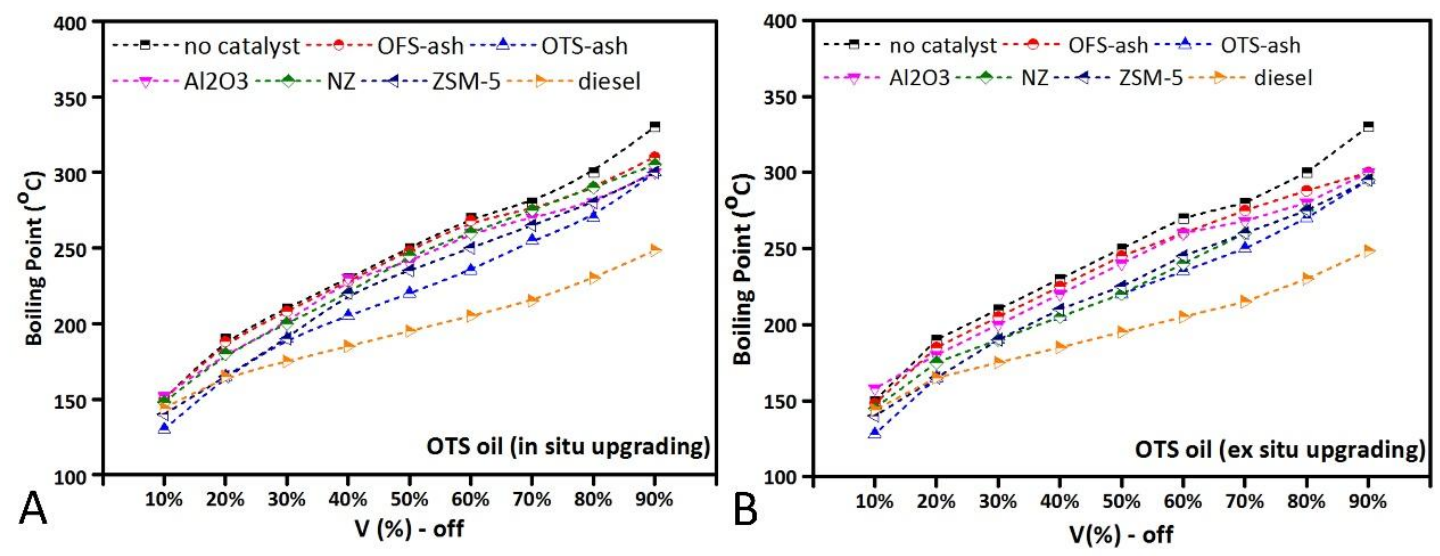

Figure 5. Boiling point range distribution of the oil product from the OTS pyrolysis $(A)$ in situ and (B) ex situ upgrading

Without using the catalysts, the ratio of remaining carbon is very high, indicating the catalysts can reduce the coke. Regarding the boiling point, there is no obvious differences between the in situ upgrading and the ex situ upgrading. As for the OFS catalytic pyrolysis, the ratios of remaining carbon in the oil products from the in situ upgrading are generally lower than those from the ex situ upgrading (Fig. 6A). In other words, the OFS oil derived from the in situ upgrading has a lower coke content than the oil product produced by the ex situ upgrading. However, in terms of the OTS catalytic pyrolysis, the ratios of remaining carbon in the oil from the in situ upgrading are generally higher than those from the ex situ upgrading (Fig. 6B). 

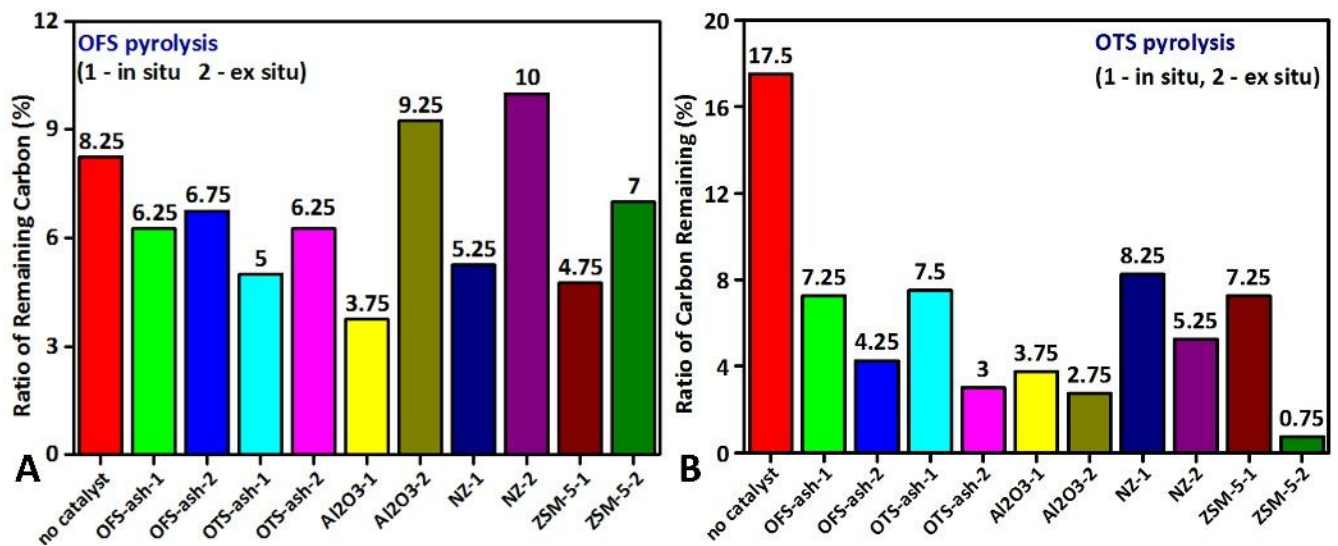

\begin{tabular}{lcccc}
\multicolumn{5}{l}{ Table 3 Mole $\mathrm{H} / \mathrm{C}, \mathrm{O} / \mathrm{C}, \mathrm{S} / \mathrm{C}$ and N/C ratios of the oil products from co-pyrolysis of OS with OS-ash } \\
\cline { 2 - 5 } & $\mathrm{H} / \mathrm{C}$ & $\mathrm{O} / \mathrm{C}$ & $\mathrm{N} / \mathrm{C}$ & S/C \\
\hline OFS pyrolysis & & & \\
no catalyst & 1.67 & 0.0131 & 0.0044 & 0.0066 \\
OFS-ash & 1.86 & 0.0038 & 0.0041 & 0.0059 \\
OTS-ash & 1.81 & 0.0039 & 0.0031 & 0.0058 \\
OTS pyrolysis & & & & \\
no catalyst & 1.68 & 0.0998 & 0.0040 & 0.0071 \\
OFS-ash & 1.89 & 0.0063 & 0.0050 & 0.0072 \\
OTS-ash & 1.83 & 0.0051 & 0.0034 & 0.0069
\end{tabular}

Figure 6. Ratio of carbon remaining of the oil products from (A) OFS pyrolysis and (B) OTS pyrolysis with different catalysts

As for the distillation characteristic of the oil products from catalytic pyrolysis of the OTS, it was found that neither the catalyst type nor the pyrolysis method significantly influenced the boiling range of the oil product, except for the oil products derived from the OTS-ash and ZSM-5. On the other hand, the ratio of remaining carbon in the oil product without the catalysts $(17.5 \%)$ is much higher than those from the catalytic pyrolysis $(0.75-8.25 \%)$. It is suggested that catalytic pyrolysis can significantly inhibit the coke formation. In addition, the mole $\mathrm{H} / \mathrm{C}, \mathrm{O} / \mathrm{C}, \mathrm{N} / \mathrm{C}$, and $\mathrm{S} / \mathrm{C}$ ratios of the oil products are shown in Table 3. With regards to both OFS and OTS, the mole H/C ratio of the oil product was increased from around 1.67 (without catalysts) to more than 1.8 (co-pyrolysis with the OFS-ash or the OTS-ash). The mole O/C ratio decreased due to the vaporization of water and halogenated metal containing oxygen. Thus, the presence of OS ash can play an important role in increasing the mole $\mathrm{H} / \mathrm{C}$ ratio and decreasing the mole $\mathrm{O} / \mathrm{C}$ ratio of the oil product. However, the mole ratios of $\mathrm{S} / \mathrm{C}$ and $\mathrm{N} / \mathrm{C}$ were not affected regularly.

\section{Table 3 Mole H/C, O/C, S/C and N/C ratios of the oil products from co-pyrolysis of OS with OS-ash}




\subsection{FT-IR Analysis}

The FT-IR analysis has been widely used for characterization of the organic functional groups with the aim of evaluating the interaction and bonding mechanism of oil products. In this study, the raw OS and the oil products derived from the pyrolysis of OS with and without the OS-ash were comparatively evaluated. The liquid and solid samples were prepared by using the cast film and pressed-pellet method, respectively. The infrared spectra of the oil products and the raw OS are shown in Fig. S1. The major vibration frequencies of the oil products are associated with the alkyl $\mathrm{C}-\mathrm{H}$ modes of vibrations, such as $-\mathrm{CH}_{2}, \mathrm{CH}_{3}$ groups. It is indicated that the relative concentrations of $-\mathrm{CH}_{2}$ and $\mathrm{CH}_{3}$ groups are higher than others. Whether OFS or OTS, except for the dominant $\mathrm{C}-\mathrm{H}$ frequency peaks, the $\mathrm{O}-\mathrm{H}$ and $\mathrm{Si}-\mathrm{O}$ groups formed by the interaction of oil, water and solid in the OS, can be observed. However, the $\mathrm{O}-\mathrm{H}$ and $\mathrm{Si}-\mathrm{O}$ frequency peaks disappeared completely. It is attributed to the separation of oil products from water and soil due to the pyrolysis process.

Furthermore, compared with the oil product without catalysts, the intensity of the $\mathrm{C}=\mathrm{C}$ stretch in aromatics decreases in the IR spectra of the oil product with the OS ash. On the contrary, the $\mathrm{C}=\mathrm{O}$ stretch in carbonyl/carboxylic become more prominent in the IR spectra of the oil product from the catalytic pyrolysis of the OFS with the OFS-ash (Fig. S1, A). It is noted that these findings are in accordance with the effect of the dehydrogenation reaction followed by the formation of ketone and olefins during the pyrolysis of oil ${ }^{[1]}$ (Table S1).

\subsection{NMR Analysis}

The results of NMR analysis are often used to speculate the molecular structure of organism, and calculate the average structural parameters of crude or heavy oil by bringing the chemical shift results into the equation list of the Brown-Ladner method ${ }^{[35]}$. Accordingly, the relative peak areas are captured in accordance with the range of: $H_{\alpha}$ (2.0-4.0 ppm); $H_{\beta}(1.0-2.0 \mathrm{ppm}) ; \mathrm{H}_{\psi}(0.5-1.0$ ppm); $H_{A}\left(9.0-6.0\right.$ ppm); $C_{A}\left(190-100\right.$ ppm); $C_{p}(70-0$ ppm). In the NMR analysis, the oil products were dissolved in deuteriated-chloroform, and analyzed by means of the ${ }^{1} \mathrm{H}$ NMR and ${ }^{13} \mathrm{C}$ NMR spectroscopy. The average structural parameters of oil products were calculated by combining the results of the ${ }^{1} \mathrm{H}$ NMR spectra, ${ }^{13} \mathrm{C}$ NMR spectra with elemental analysis. The main equations and parameters are listed in Table S2. It should be noteworthy that the Brown-Ladner method is established under two assumed conditions: $(1) \mathrm{H}_{s} / \mathrm{C}_{s} \approx 2$, where $\mathrm{H}_{\mathrm{s}}$ is the number of the saturated 
hydrogen, $\mathrm{C}_{\mathrm{s}}$ is the number of the saturated carbon; (2) Only $\mathrm{C}$ and $\mathrm{H}$ exits in the oil products. Herein, the $\mathrm{H}_{s} / \mathrm{C}_{s}$ of the tested oil products are in the range of 2.12-1.87. The mass fractions of $\mathrm{C}+\mathrm{H}$ of the oil products are higher than $96.5 \%$. Therefore, the actual situation of the oil products is generally in line with the two assumed conditions.

Six groups of average structural parameter of oil products (A-F) are calculated as shown in Fig. 7. Fig. 7A shows the ratios of the aliphatic carbon, the naphthenic carbon, and the aromatic carbon of the oil products, in which the main part of the carbon exists in the form of the aliphatic carbon, corresponding to the result of FT-IR analysis. Due to the hydrogenation of the aromatics and in the presence of catalyst, the ratio of the aliphatic carbon of the oil sample increases from $65 \%$ (in $A$ and $D$ ) to higher than $77 \%$ (in $B, C, E$ and $F$ ). This increase is especially remarkable in the case with the OFS-ash, which might be attributed to the high nickel content, thereby enhancing the hydrogenation of the oil products. Although no extra hydrogen is added to the reactor, the presence of the paraffinic structure in the raw OS provides a source of hydrogen donor in the hydrogenation. Furthermore, the decarburization, which is presented by the formation of coke, during the pyrolysis process, can reduce the ratio of the naphthenic carbon and the aromatic carbon in the oil products.

The number of aromatic ring, naphthenic rings including $R_{A}$ and $R_{N}$, and the average chain length of aliphatic chain or side chain (L) can reflect the average molecular structure of the oil product visually (Fig. 7 C). Each molecule of sample $A$ and $B$ contain about three aromatic rings and two and a half naphthenic rings in average. After catalytic pyrolysis with the OFS-ash and the OTS-ash, the aromatic ring numbers decrease to $0.8-1.6$ and $1.5-1.9$, respectively, which might be caused by the hydrogenation and ring-open of naphthenic hydrocarbon during the catalytic pyrolysis. As for the decrease of the average chain length of the oil product, it might also be attributed to the de-methylation of alkanes over the OFS-ash (B and E). 

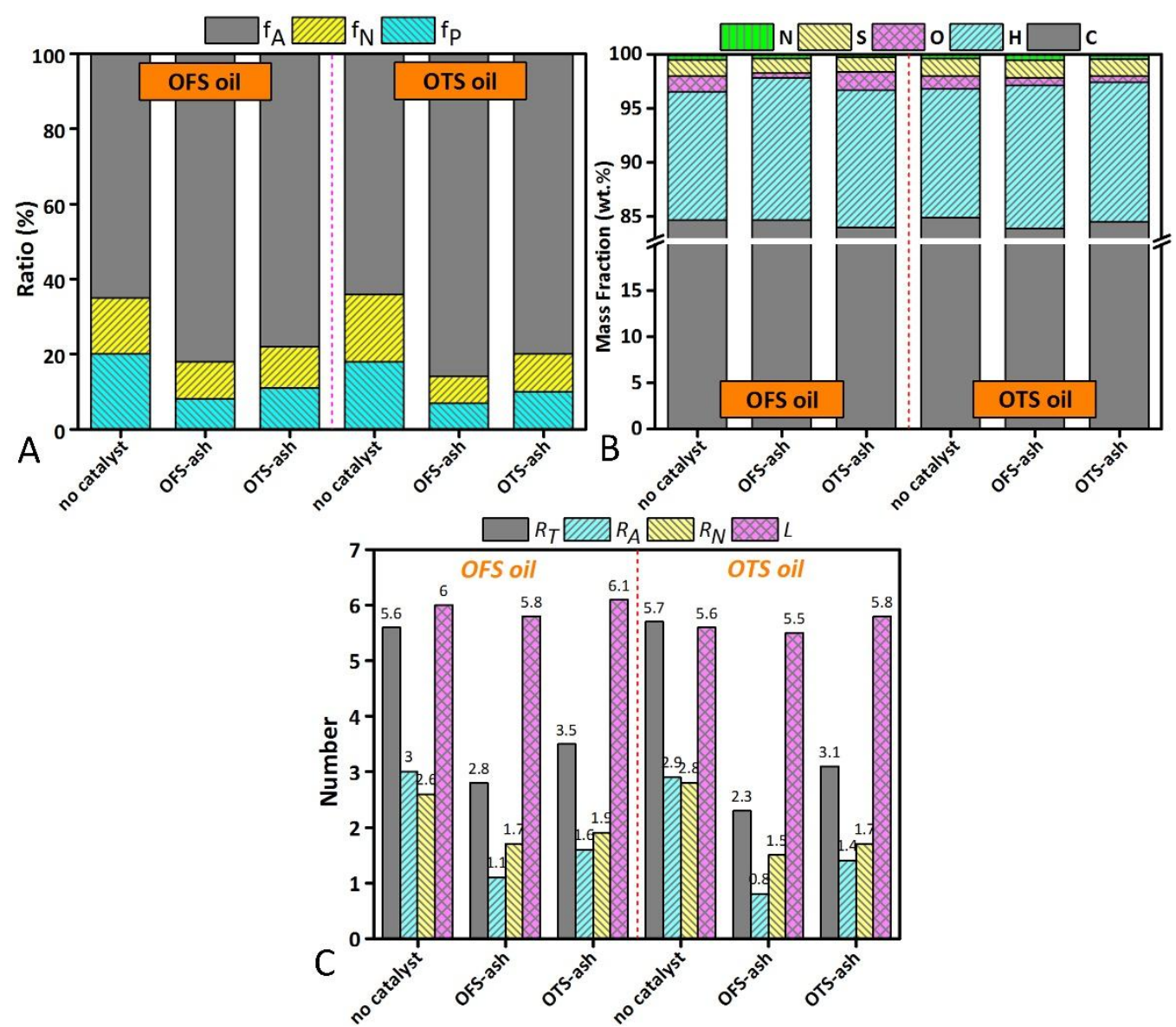

Figure 7. (A) Ratio of aliphatic, naphthenic, and aromatic carbon obtained from the NMR spectra, (B) mass fraction of elements, and (C) distribution of ring number of the oil from the co-pyrolysis of the OS with and without the OS-ash.

\subsection{Fuel Characteristics of the Oil Products Blended with Diesel}

In the previous studies, it has been shown that the characteristics of oil products derived from OS catalytic pyrolysis are similar to the commercial diesel. However, it still contains some impurities and vacuum residues. The oil products from the catalytic pyrolysis of the OFS with the OFS-ash, and from the catalytic pyrolysis of the OTS with the OTS-ash were blended with the commercial diesel (the diesel standard) by one-to-five and one-to-ten volume ratios. Herein, these two oil products were chosen in the view of commercialization for two reasons: (1) The presence of OS ash in the in situ upgrading improves the yield and quality of the oil product; (2) The source of OS-ash as a pyrolytic residue can be produced followed by the pyrolysis of OS.

The oil mixtures were filtered using $0.8 \mu \mathrm{m}(47 \mathrm{~mm})$ pore size filter film to remove the insoluble impurities and vacuum residues. The kinematic viscosity, the density, the higher heating value (HHV), and the catene index are summarized in Table 4. All the oil mixtures have higher HHV than 
the commercial diesel. For the same oil product, HHV of the fuel with the mixing ratio of 1:10 is higher than that of 1:5. It means that the mixing ratio of 1: 10 can well support the burning and heat release of the mixed fuel. And the catena index, which reflects the ignition characteristics of a diesel range fuel, of these mixed fuels shows the same tendency with HHV. As for the chemical components, the fuel samples were analyzed by using the GC-MS. The chromatograms of the fuel samples from GC-MS analysis were compared with the results of GC-FID, and the main identified components are listed in Table S3. Based on the peak area (\%) and the component names, the carbon distillation and the oil compositions were calculated and the results are presented in Fig. 8 and 9.

Table 4 Kinematic viscosity, density, heating value, and cetane index of the diesel blended with oil

\begin{tabular}{cccc} 
Kinematic & Density & Heating value & Cetane index \\
viscosity $\left(40^{\circ} \mathrm{C}\right)$ & $\left(20 \mathrm{~g} / \mathrm{cm}^{3}\right)$ & $(\mathrm{MJ} / \mathrm{kg})$ & \\
\hline
\end{tabular}

OFS oil (in situ, ofs-ash) : diesel

$\begin{array}{ccccc}1: 5 & 2.53 & 0.819 & 45.7 & 38.22 \\ 1: 10 & 2.52 & 0.812 & 46.1 & 38.51\end{array}$

OTS oil (in situ, ots-ash) : diesel

$\begin{array}{lllll}1: 5 & 2.54 & 0.813 & 45.3 & 37.53 \\ 1: 10 & 2.50 & 0.810 & 45.8 & 37.58 \\ \text { lstandard) } & 2.49 & 0.809 & 45.2 & 35.44\end{array}$

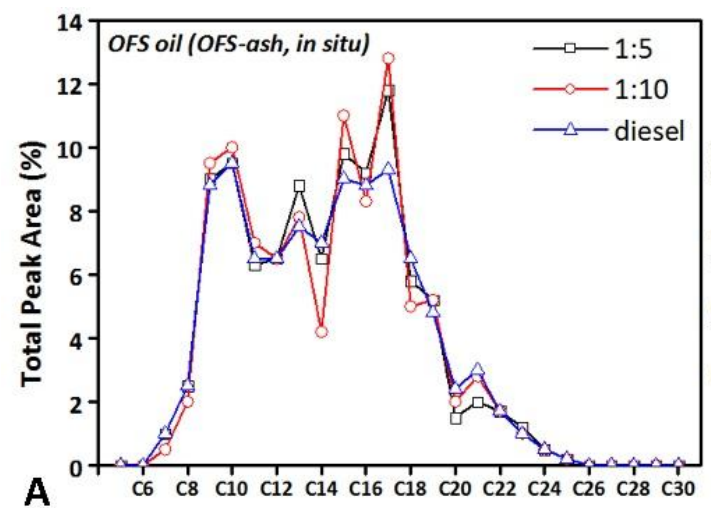

It could be found that the range of carbon distribution of these mixed fuels (C7-C26) is identical with the diesel (Fig. 8). However, the distribution curve of the oil-diesel mixtures with the mixing ratio of 1:10 presented a strong fluctuation in the range of $\mathrm{C} 12-\mathrm{C} 17$. Therefore, it is indicated that the mixture of the oil product and diesel might not be a simple mixing of chemical components.

Figure 8. Carbon distribution of the mixed fuels of diesel with the oil product from co-pyrolysis of (A) the OFS with the OFS-ash and (B) the OTS with the OTS-ash. 
Some unknown interactions occurred between the chemical components in the oil product and diesel, thereby influencing the results of GC-MS detection. The mixed fuels and diesel could be divided into saturates: alkane and cycloalkane; olefin; aromatics; and non-hydrocarbon: resin and heterocyclic (Fig. 9). It can be found that the saturate content of the mixed fuel increased with the increase of the oil product proportion. On the other hand, the compositions of aromatic and non-hydrocarbon decreased with the increase of the oil proportion. Combined with HHV and the cetane index results above, it is anticipated that the addition of pyrolytic oil product can improve the quality of diesel oil to some extent.

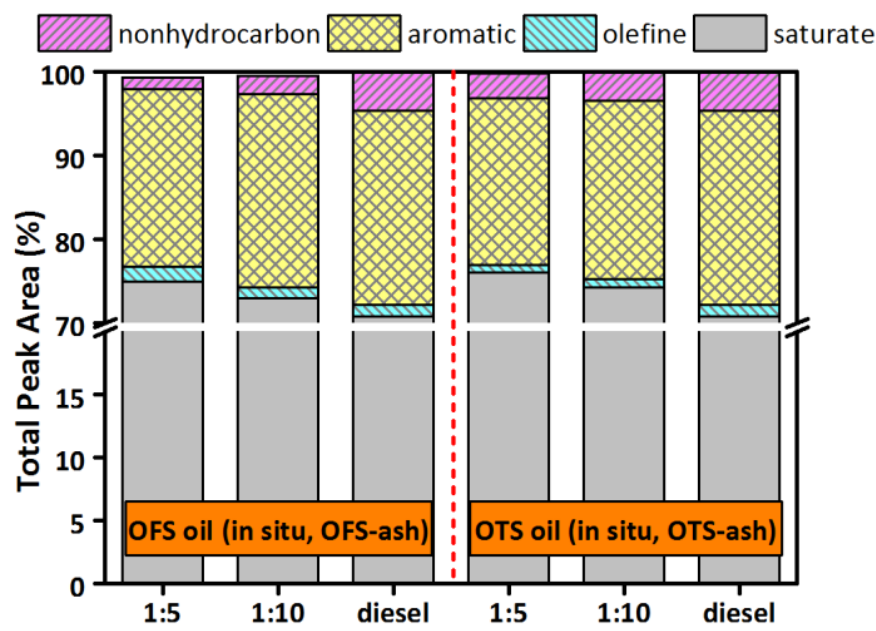

Figure 9. Chemical composition of the mixed fuels of diesel and oil from co-pyrolysis of the OS with the OS-ash.

\section{CONCLUSIONS}

The yield of the oil products of the in situ upgrading is higher than that of the ex situ upgrading. The highest yield of oil product is about 35.5\% from the OTS co-pyrolysis with the OFS-ash. It can be partially attributed to the presence of iron and sulfur elements in the OFS-ash. Co-pyrolysis with the OFS-ash could improve the contact between the OS and the catalyst. Compared with the OFS, oil recovery from the OTS is more considerable. However, the OFS-ash possesses a better catalytic performance on the pyrolysis vapor upgrading because of high metal (e.g., iron, nickel) contents. Moreover, the boiling point range of all the oil products are between that of the oil and diesel standard. In the catalytic pyrolysis of the OFS, the quality of the oil products was improved by decreasing the boiling point range. In terms of the distillation characteristics, the OTS-ash and ZSM-5 could significantly affect the boiling range of the oil products. 
1 The main carbon form in the oil product from the OS pyrolysis with the OS-ash is aliphatic carbon.

2 The total ring number of the oil products decreased due to the hydrogenation and ring-open of

3 naphthenic hydrocarbon in the catalytic pyrolysis. In addition, the highest HHV and cetane index (46.1 MJ/kg and 38.51) could be obtained, when the oil product from the co-pyrolysis of the OFS with the OFS-ash was blended with the diesel with the mixing ratio of one-to-ten. The range of carbon distillation of the mixed fuels (C7-C26) was identical with the diesel. The saturate contents of the mixed fuel increased with the increase of the oil product proportion. Combining HHV with cetane index results, the addition of the oil product from OS pyrolysis could slightly improve the quality of diesel oil.

\section{ACKNOWLEDGEMENTS}

This work is financially supported by the Startup Fund for Introducing Talents at NUIST under Grant no. 2243141501046. The authors are gratefully to acknowledge the financial supports by the National Science Foundation of China (no. 21407079, 21577065, 91543115 and 91544220 ).

\section{REFERENCES}

[1] Ma Z, Gao N, Xie L, Li A. Study of the fast pyrolysis of oilfield sludge with solid heat carrier in a rotary kiln for pyrolytic oil production. J. Anal. Appl. Pyrolysis 2014; 105: 183-90.

[2] Zhu W, Tang J, Wang F, Lin D. Pollution of oil sludge and its disposal techniques in China and abroad. Petrochemical Industry Application, 2014. (In Chinese)

[3] Okieimen CO, Okieimen FE. Effect of natural rubber processing sludge on the degradation of crude oil hydrocarbons in soil. Bioresour. Technol. 2002; 82(1): 95-7.

[4] Ramaswamy B, Kar DD, De S. A study on recovery of oil from sludge containing oil using froth flotation. J. Environ. Manage. 2007; 85(1): 150-4.

[5] Jin Y, Zheng X, Chu X, Chi Y, Yan J, et al. Oil recovery from oil sludge through combined ultrasound and thermochemical cleaning treatment. Ind. Eng. Chem. Res. 2012; 51: 9213-7.

[6] Zheng C, Wang M, Wang $Y$, Huang Z. Optimization of biosurfactant-mediated oil extraction from oil sludge. Bioresour. Technol. 2012; 110: 338-42.

[7] Wang Z, Guo Q, Liu X, Cao C. Low temperature pyrolysis characteristics of oil sludge under various heating conditions. Energy Fuels 2007; 21: 957-62.

[8] Qin L, Han J, He X, Zhan Y, Yu F. Recovery of energy and iron from oily sludge pyrolysis in a fluidized bed reactor. J. Environ. Manage. 2015; 154: 177-82.

[9] Sankaran S, Pandey S, Sumathy K. Experimental investigation on waste heat recovery by 
refinery oil sludge incineration using fluidised bed technique. J. Environ. Sci. Heal. A 2008; 33: 829-45.

[10] Wei YL, Wu CH. PAH emissions from the fluidized-bed incineration of an industrial sludge. J. Air Waste Manage. 2012; 47: 953-60.

[11] Schmidt H, Kaminsky W. Pyrolysis of oil sludge in a fluidized bed reactor. Chemosphere 2001; 45: 285-90.

[12] Wang Z, Guo Q, Liu X, Cao C. Low temperature pyrolysis characteristics of oil sludge under various heating conditions. Energy Fuels 2007; 21: 957-62.

[13] Karayildirim T, Yanik J, Yukel M, Bockhom H. Characterisation of products from pyrolysis of waste sludges. Fuel 2006; 85: 1498-508.

[14] Shie J, Lin J, Chang C, Shih S, Lee D, et al. Pyrolysis of oil sludge with additives of catalytic solid wastes. J. Anal. Appl. Pyrolysis 2004; 71: 695-07.

[15] Chang C, Shie J, Lin J, Wu C, Lee D, et al. Major products obtained from the pyrolysis of oil sludge. Energy Fuels 2000; 14: 1176-83.

[16] Shie J, Chang C, Lin J, Lee D, Wu C. Use of inexpensive additives in pyrolysis of oil sludge. Energy Fuels 2001; 16: 102-8.

[17] Shen Y, Yoshikawa K. Tar conversion and vapor upgrading via in-situ catalysis using silica-based nickel nanoparticles embedded in rice husk char for biomass pyrolysis/gasification. Ind. Eng. Chem. Res. 2014; 53 (27): 10929-42.

[18] Shen Y, Chen M, Sun T, Jia J. Catalytic reforming of pyrolysis tar over rice husk char supported metallic nickel nanoparticles. Fuel 2015; 159: 570-9.

[19] Carpenter D, Westover TL, Czernik S, Jablonski W. Biomass feedstocks for renewable fuel production: a review of the impacts of feedstock and pretreatment on the yield and product distribution of fast pyrolysis bio-oils and vapors. Green Chem. 2014; 16: 384-406.

[20] Luo G, Resende FLP. In-situ and ex-situ upgrading of pyrolysis vapors from beetle-killed trees. Fuel 2016; 166: 367-75.

[21] Lam SS, Liew RK, Jusoh A, Chong CT, Ani FN, Chase HA. Progress in waste oil to sustainable energy, with emphasis on pyrolysis techniques. Renew. Sust. Energy Rev. 2016; 53: 741-53.

[22] Lam SS, Liew RK, Cheng CK, Chase HA. Catalytic microwave pyrolysis of waste engine oil using metallic pyrolysis char. Appl. Catal. B: Environ. 2015; 176-177: 601-17.

[23] Lam SS, Russell AD, Lee CL, Chase HA. Microwave-heated pyrolysis of waste automotive engine oil: Influence of operation parameters on the yield, composition, and fuel properties of pyrolysis oil. Fuel 2012; 92: 327-39.

[24] Lam SS, Russell AD, Lee CL, Lam SK, Chase HA. Production of hydrogen and light hydrocarbons as a potential gaseous fuel from microwave-heated pyrolysis of waste automotive engine oil. Int J Hydrog Energy 2012; 37: 5011-21. 
[25] Lam SS, Russell AD, Chase HA. Pyrolysis using microwave heating: A sustainable process for recycling used car engine oil. Ind. Eng. Chem. Res. 2010; 49: 10845-51.

[26] Wang H, Dai F, Li Z, Li C. Upgrading shale oil distillation to clean fuel by coupled hydrogenation and ring opening reaction of aromatics on $\mathrm{W}-\mathrm{Ni} / \mathrm{V}-\mathrm{Al}_{2} \mathrm{O}_{3}$ catalysts. Energy Fuels 2015; 29: 4902-10.

[27] Wang $\mathrm{H}$, Jiao T, Li Z, Li C, Zhang S, Zhang J. Study on palm oil hydrogenation for clean fuel over Ni-Mo-W/ $/ \mathrm{Al}_{2} \mathrm{O}_{3}-\mathrm{Al}_{2} \mathrm{O}_{3}-\mathrm{ZSM}-5$ catalyst. Fuel Process. Technol. 2015; 139: 91-9.

[28] Wang H, Cao Y, Li D, Muhammad U, Li C, Li Z, Zhang S. Catalytic hydrorefining of tar to liquid fuel over multi-metals (W-Mo-Ni) catalysts. J. Renewable Sustainable Energy 2013; 5: 053114.

[29] Iliopoulou EF, Stefanidis SD, Kalogiannis KG, Delimitis A, Lappas AA, Triantafyllidis KS. Catalytic upgrading of biomass pyrolysis vapors using transition metal-modified ZSM- 5 zeolites. Appl. Catal. B: Environ. 2012; 127: 281-90.

[30] Zhang X, Lei H, Yadavalli G, Zhu L, Wei Y, Liu Y, Gasoline-range hydrocarbons produced from microwave-induced pyrolysis of low-density polyethylene over ZSM-5. Fuel 2015; 144: 33-42.

[31] Dorado C, Mullen CA, Boateng AA. H-ZSM5 catalyzed co-pyrolysis of biomass and plastics. ACS Sustain. Chem. Eng. 2014; 2: 301-11.

[32] Zhang X, Lei H, Zhu L, Qian M, Zhu X, Wu J, Chen S. Enhancement of jet fuel range alkanes from co-feeding of lignocellulosic biomass with plastics via tandem catalytic conversions. Appl. Energy 2016; 173: 418-30.

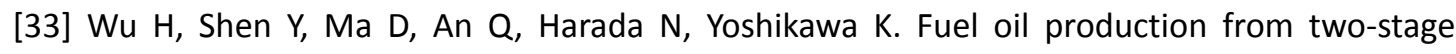
pyrolysis-catalytic reforming of brominated high impact polystyrene using zeolite and iron oxide loaded zeolite catalysts. Open Journal of Ecology 2015; 5: 136-46.

[34] Wu H, Shen Y, Harada N, An Q, Yoshikawa K. Production of pyrolysis oil with low bromine and antimony contents from plastic material containing brominated flame retardants and antimony trioxide. Energy and Environment Research 2014; 4: 105-18.

[35] Brown JK, Landner WR. A study of the hydrogen distribution in coal-like materials by high-resolution nuclear magnetic resonance spectroscopy 1. A comparison with infra-red measurement and the conversion to carbon structure. Fuel 1960; 39: 87-96. 


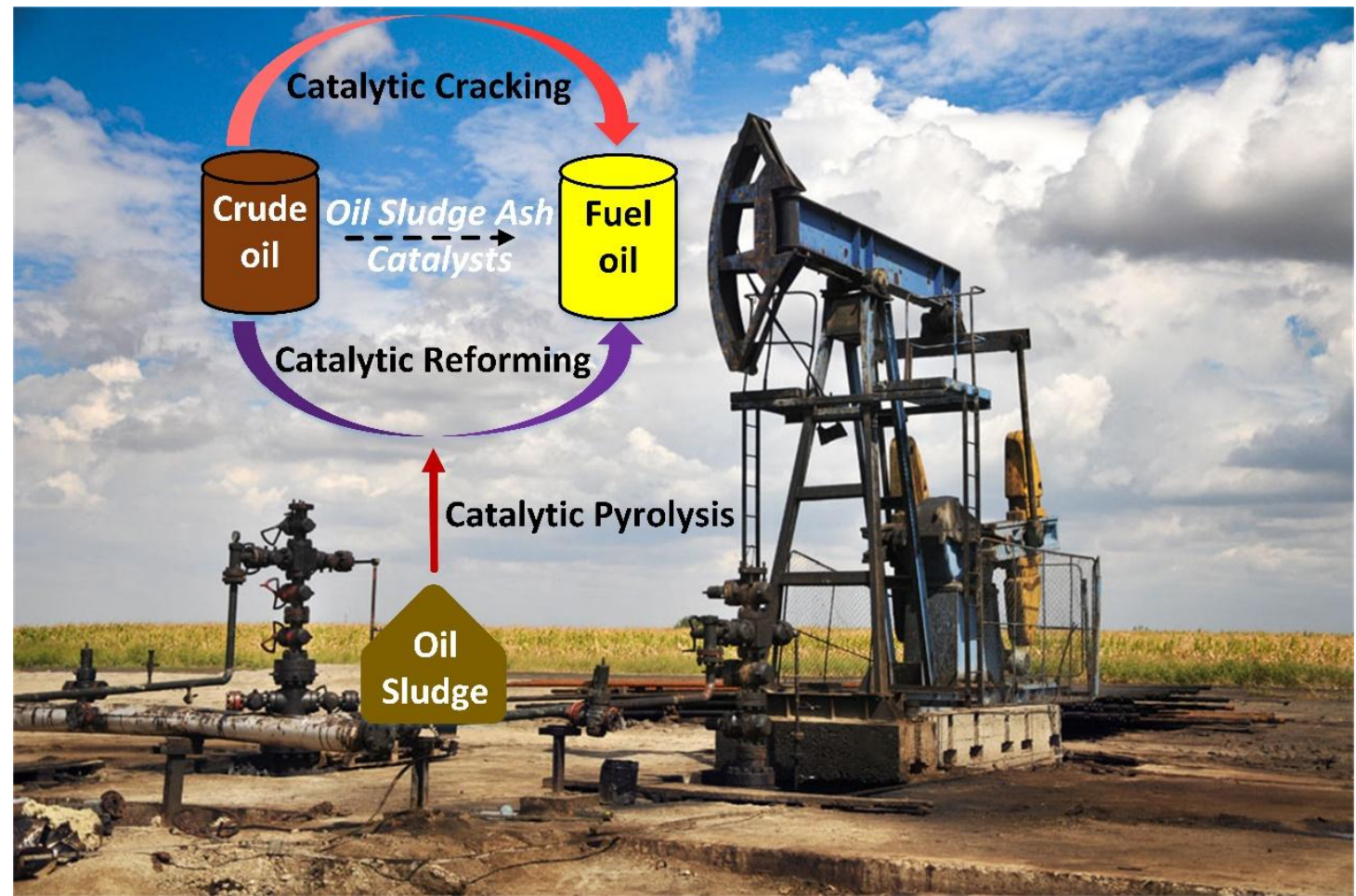

2 